Kapata Arkeologi, 12(1), 43-58

ISSN (cetak): 1858-4101

ISSN (elektronik): 2503-0876

http://kapata-arkeologi.kemdikbud.go.id

\title{
ARKEOLOGI KEPULAUAN TANIMBAR BAGIAN UTARA: TINJAUAN POTENSI DI PULAU FORDATA DAN PULAU LARAT MALUKU INDONESIA
}

\section{The Archaeology of Northern Tanimbar Islands: A Potential Overview of Fordata and Larat Island Moluccas Indonesia}

\author{
Marlon NR Ririmasse \\ Balai Arkeologi Maluku - Indonesia \\ Jl.Namalatu-Latuhalat Ambon Indonesia 97118 \\ ririmasse@yahoo.com
}

Naskah diterima: 17/09/2016; direvisi: 17/11 - 16/12/2016; disetujui: 16/12/2016

Publikasi ejurnal: 30/12/2016

\begin{abstract}
Tanimbar islands is one of the most southern island group in Maluku. This area is a land bridge that connects Kei-Aru Islands and Papua with the Babar-Sermata Islands until Timor. Directly adjacent to Australia, Tanimbar is also an area of the outer boundary of Indonesia. This area is also known for its rich variety of cultural heritage. As reflected in the academics works and diverse collection of Tanimbar material culture in various world museum. Archaeological study have been conducted since 2006 but only covered the southern part of this archipelago. This paper is the result of the archaeological studies in the Northern Part of the Tanimbar Islands with the focus on Fordata and Larat Island. The reconaissance survey have been adopted as the approach in this research. This study found that the island of Larat and Fordata is rich with the archaeological potential and is recommended to be followed with the further research in the future.
\end{abstract}

Keywords: Archaeology, Potential Overview, Larat Island, Fordata Island

\begin{abstract}
Abstrak
Kepulauan Tanimbar merupakan salah satu gugus pulau paling selatan yang terletak di Maluku. Wilayah ini merupakan jembatan darat yang menghubungkan antara Kepulauan Kei-Aru dan Papua dengan Kepulauan Babar-Sermata hingga Timor dan Nusa Tenggara. Berbatasan langsung dengan Australia, Kepulauan Tanimbar juga merupakan kawasan tapal batas terluar Nusantara. Wilayah ini juga dikenal dengan ragam pusaka budaya yang kaya. Sebagaimana ditemukan dalam karya akademis dan ragam koleksi benda budaya Tanimbar di berbagai museum dunia. Studi arkeologi telah dilakukan sejak tahun 2006 namun hanya menjangkau wilayah bagian selatan dan tenggara kepulauan ini. Makalah ini merupakan hasil studi arkeologis untuk wilayah Tanimbar Bagian Utara dengan perhatian pada Pulau Fordata dan Pulau Larat. Pendekatan yang digunakan dalam penelitian ini adalah survei penjajakan. Hasil penelitian menemukan bahwa Pulau Fordata dan Pulau Larat kaya dengan potensi kepurbakalaan dan layak ditindaklanjuti dengan studi arkeologis yang lebih mendalam.
\end{abstract}

Kata Kunci: Arkeologi, Tinjauan Potensi, Pulau Larat, Pulau Fordata

\section{PENDAHULUAN}

Himpunan perahu motor beriringan menuju kapal. Berjejer rapi bergerak dengan buih-buih gelombang mengikuti di belakang. Perlahan-lahan mereka tiba di tepi lambung kapal Sabuk Nusantara 34 yang kami tumpangi. Salah satu armada pelayaran perintis yang menghubungkan pulau-pulau yang ada di belahan selatan Maluku ,yang mengantar kami sepanjang malam menyusuri pesisir timur Pulau Yamdena.

Hari itu, menjelang tengah hari pada pertengahan bulan Maret 2014, tim penelitian Balai Arkeologi Ambon tiba di lepas pantai Fordata. Salah satu pulau di belahan utara Kepulauan Tanimbar. Dari atas kapal kami 
memandang ke arah Romean, salah satu desa yang menjadi tujuan kunjungan tim, sambil menggendong ransel. Menunggu giliran turun ke perahu motor yang akan mengantar kami dari kapal menuju pantai. Belum ada dermaga yang memadai di Pulau ini. Tak heran bila semua penumpang kapal, baik dewasa hingga anakanak, harus berjejal-jejal turun dengan hati-hati di atas perahu motor sebelum mencapai daratan. Termasuk seorang ibu yang menggendong bayi dalam balutan kain.

Fordata, bersama Larat, adalah dua pulau yang menjadi lokasi penelitian tim Balai Arkeologi Ambon pada triwulan pertama tahun 2014 ini. Sejatinya kami berkeinginan untuk juga bisa meninjau pulau-pulau yang lebih ke utara seperti Molu Maru. Namun keterbatasan waktu, kondisi cuaca dan geografis, membuat niat itu harus ditunda. Mungkin hingga tahun mendatang. Lepas dari kondisi tersebut, pengamatan yang dilakukan di Fordata dan Larat memang sudah saatnya dilakukan.

Selama ini studi arkeologi di Kepulauan Tanimbar sudah mulai intensif dilakukan. Utamanya semenjak tahun 2011. Namun rangkaian riset tersebut hanya menjangkau wilayah bagian selatan Kepulauan Tanimbar. Meliputi pesisir timur dan barat daya Pulau Yamdena sebagai pulau utama hingga Pulau Selaru yang menjadi daratan paling selatan di gugus pulau ini. Padahal ditinjau secara geografis, wilayah bagian utara Tanimbar juga memiliki rupa alam yang sama kompleksnya. Demikian halnya bila ditinjau dari potensi sejarah budaya yang juga beragam. Bila mengacu pada sumber-sumber historis yang pernah merekam kondisi wilayah ini di masa lalu. Hal ini yang kemudian menjadi pertimbangan utama bagi Balai Arkeologi Ambon untuk melakukan studi penjajakan guna menemukenali potensi arkeologi dan sejarah budaya yang ada di wilayah Kepulauan Tanimbar Bagian Utara sebagaimana dipaparkan dalam artikel ini.

\section{Rumusan Masalah}

Kepulauan Tanimbar merupakan salah satu gugus pulau utama yang ada di Maluku. Terletak di belahan selatan Maluku, kepulauan ini membentuk rantai gugus pulau yang jalin menjalin dengan Kepulauan Aru, Kepulauan Kei, hingga Kepulauan Babar dan Pulau-Pulau Selatan Daya yang berdekatan dengan Pulau
Timor. Berbatasan langsung dengan Australia, Tanimbar juga merupakan rumah bagi beberapa pulau terdepan. Studi arkeologis telah dilaksanakan dengan cukup memadai di kepulauan ini, namun umumnya hanya menjangkau wilayah bagian selatan kepulauan Tanimbar. Pulau-pulau di Tanimbar Bagian Utara belum mendapat perhatian yang semestinya meski dari segi potensi budaya dipandang memiliki keragaman yang juga raya. Penelitian ini merupakan langkah awal untuk menemukenali potensi arkeologi dan sejarah budaya yang ada di wilayah Tanimbar Bagian Utara dengan fokus studi di Pulau Fordata dan Larat. Untuk itu pertanyaan penelitian yang menjadi basis penelitian ini adalah:

1. Bagaimanakah karaktersitik potensi arkeologi yang ada di Pulau Larat dan Fordata di Kepulauan Tanimbar Bagian Utara?

2. Bagaimanakah prospek pengembangan segenap potensi ini ke depan?

\section{Tujuan Penelitian}

Berpijak pada rumusan masalah di atas maka tujuan penelitian di wilayah Tanimbar Bagian Utara ini adalah:

1. Menemukenali potensi arkeologi dan kepurbakalaan yang ada di Pulau Fordata dan Pulau Larat di Tanimbar Bagian Utara

2. Membuka ruang diskusi terkait kemungkinan arah pengembangan segenap potensi yang direkam dalam kaitan dengan studi arkeologi dalam kawasan.

\section{METODE}

Penelitian ini dilakukan pada bulan Februari 2014 selama dua puluh hari penelitian. Lokasi penelitian difokuskan di Pulau Larat dan Fordata, Kabupaten Maluku Tenggara Barat, Propinsi Maluku, Indonesia. Sebagai studi inisiasi untuk menemukenali potensi, maka pendekatan penelitian yang digunakan adalah survei penjajakan (reconiassance survey). Melalui pendekatan ini segenap potensi kepurbakalaan yang ada akan diidentifikasi melalui survei permukaan dan direkam secara verbal dan visual. Termasuk data yang akan direkam adalah pengetahuan masyarakat setempat terkait potensi arkeologis dimaksud dalam bentuk sejarah tutur. Kajian juga akan diperkuat dengan pendekatan studi pustaka untuk menghimpun referensi sejarah budaya dan 
aspek yang relevan terkait lokasi penelitian serta pengetahuan konseptual yang dipandang mampu memperkaya penelitian ini.

\section{HASIL DAN PEMBAHASAN}

\section{Kepulauan Tanimbar: Profil Lokasi Penelitian dan Rekam Studi Arkeologis}

Kepulauan Tanimbar secara administratif merupakan bagian dari Kabupaten Maluku Tenggara Barat dengan ibu kota, Saumlaki. Wilayah ini merupakan bagian dari Provinsi Maluku dan dibentuk sebagai kabupaten mandiri pada tahun 1999. Sebutan untuk Kepulauan Tanimbar sendiri mengacu kepada gugus pulau yang terletak di sebelah selatan Kepulauan Banda. Geografi Kepulauan ini berbatasan dengan Kepulauan Kei di sebelah timur dan
Beberapa pulau utama lain adalah Selaru, Fordata, Wuliaru dan Sera. Pulau paling utara adalah Pulau Molu dan pulau paling selatan adalah Selaru. Pulau Selaru merupakan salah satu dari sembilan puluh enam pulau terluar di Indonesia (Ririmasse, 2010b). Dalam bentang luas kepulauan ini hidup lebih dari 100,000 jiwa penduduk. Masyarakat Tanimbar berbicara dalam lima bahasa berbeda. Bahasa dengan kelompok penutur terbesar adalah bahasa Yamdena, diikuti bahasa Fordata, Bahasa Selaru, Bahasa Seluwasa dan Bahasa Makatian. Kelompok bahasa ini merupakan bagian dari rumpun bahasa Austronesia, Central Easter Malayo-Polynesian (Ririmasse, 2010a; Le Bar, 1976). Hampir seluruh penduduk di Kepulauan Tanimbar saat ini menganut agama Nasrani.

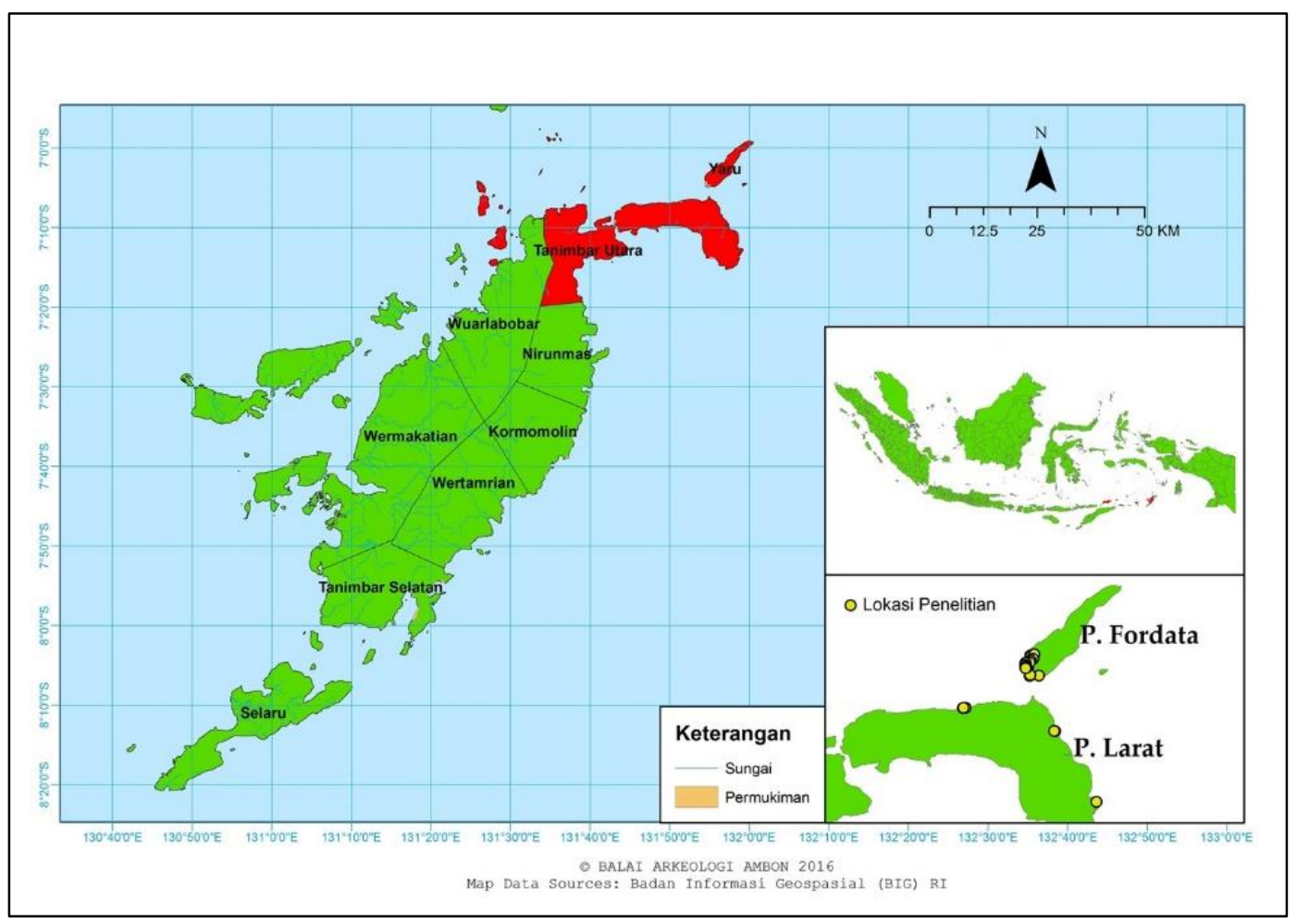

Gambar 1. Fokus wilayah penelitian Pulau Fordata dan Pulau Larat dalam Peta Kepulauan Tanimbar dengan sebaran situs yang didata berwarna kuning

(Sumber: Balai Arkeologi Maluku, 2016)

Kepulauan Babar di sebelah barat. Laut Banda menjadi pembatas di utara sementara Laut Arafura dan Australia menjadi pembatas di selatan.

Gugus Kepulauan Tanimbar dibentuk oleh lebih dari 174 pulau yang membentuk wilayah seluas $53,251 \mathrm{~km}^{2}$. Pulau terbesar dalam Kepulauan Tanimbar adalah Yamdena.
Namun praktek-praktek religi lama masih dapat diamati dalam profil budaya tradisional masyarakat.

Sumber-sumber historis terkait Kepulauan Tanimbar umumnya diinisiasi oleh para pendatang Eropa. Mereka memiliki latar belakang petugas pemerintah kolonial hingga misionaris agama. J.G.F. Riedel dan van Hoevell 
adalah dua nama yang cukup dikenal (Ririmasse, 2011a). Kehadiran mereka terkait upaya menjalankan kebijakan pasifikasi yang diterapkan pemerintah kolonial Hindia Belanda di seluruh Kepulauan Maluku Tenggara. Riedel dan van Hoevel juga banyak menyumbangkan koleksi etnografi Tanimbar ke museum-museum di Eropa. Beberapa objek bahkan ditampilkan sebagai bagian dari koleksi mahakarya di museum-museum terkemuka di Benua Biru. Misi Katolik masuk ke Tanimbar pada tahun 1907 sementara misi Protestan masuk setelah Perang Dunia ke-2. Di antara para misionaris yang datang, Petrus Drabbe adalah salah seorang yang paling menonjol. Kontribusi Drabbe bagi studi akademis di wilayah ini diwakili oleh karyanya terkait budaya Tanimbar yang berjudul Etnografie Tanimbar. Selepas Drabbe, nyaris tak ada karya akademik dengan bobot signifikan terkait Kepulauan ini. Sebelum akhirnya seorang antropolog asal Amerika Serikat, Susan McKinnon (1988), menerbitkan karyanya terkait studi antropologis atas wilayah ini dengan fokus pada Pulau Fordata.

Kondisi serupa juga ditemukan dalam konteks studi arkeologis yang masih cukup minimal dilakukan di wilayah ini. Beberapa penelitian telah dilaksanakan sebelumnya, namun masih dalam bentuk tinjauan awal dengan fokus masalah dan wilayah kajian yang sangat terfragmentaris. Penelitian arkeologis paling awal di Kepulauan Tanimbar dilakukan oleh Intan (2004) yang merekam potensi sumber daya arkeologis di Sangliat Dol. Penelitian berikutnya dilakukan oleh Sudarmika yang meninjau kembali profil perahu batu di Sangliat Dol dan Fordata (Ririmasse, 2005). Dalam penelitian ini direkam jejak budaya berupa monumen perahu batu dan pemukiman tradisional. Tahun 2006 Ririmasse dan Sudarmika melakukan survei arkeologis di Pulau Selaru yang terletak di selatan Yamdena (Ririmasse, 2007). Fokus penelitian diarahkan di sekitar kawasan situs Enus. Hasil pengamatan merekam keberadaan situs bekas pemukiman kuna dan sebaran tinggalan Jepang dari masa Perang Pasifik. Meski terbatas, himpunan tinjauan awal atas Kepulauan Tanimbar ini merupakan rujukan berarti sebagai landasan kajian lanjutan di wilayah ini. Tahun 2011 Balai Arkeologi Ambon melakukan survei eksploratif untuk mengamati sebaran pemukiman kuna dan potensi arkeologis yang ada di pesisir timur
Pulau Yamdena, sebagai pulau terbesar di Kepulauan Tanimbar. Hasil studi ini kemudian ditindaklanjuti pada tahun 2012 dengan melakukan ekskavasi di situs pemukiman kuna di situs Sangliat Dol dan Arui Bab telah diidentifikasi pada tahun sebelumnya. Studi arkeologis atas Kepulauan Tanimbar kemudian diperluas dengan melakukan pengamatan atas Pulau Selaru sebagai salah satu pulau terdepan Indonesia pada tahun 2013. Pada tahun ini survei yang hampir menyeluruh dilakukan atas Selaru sebagai pulau terselatan di gugus Kepulauan Tanimbar.

Penelitian yang dilakukan kali ini difokuskan pada kawasan Tanimbar Bagian Utara. Khususnya di Pulau Larat dan Fordata. Pulau Larat memiliki nilai strategis karena merupakan salah satu dari sembilan puluh dua pulau terdepan yang ada di Indonesia. Studi budaya atas wilayah ini merupakan suatu keharusan. Pulau Fordata memiliki nilai penting dari sisi sejarah budaya sebagaimana dapat diacu pada beberapa sumber asing yang menyebutkan mengenai wilayah ini.

\section{Potensi Arkeologi di Pulau Larat dan Fordata: Hasil Survei}

Lokasi penelitian di Fordata dan Larat dapat dicapai dari Ambon dengan menggunakan pesawat terbang dan angkutan laut. Dalam penelitian ini tim berangkat dari Ambon menggunakan pesawat terbang dan tiba di Saumlaki, Ibu Kota Kabupaten Maluku Tenggara Barat pada hari yang sama. Perjalanan kemudian dilanjutkan dengan menggunakan kapal laut khas pelayaran perintis menuju pulau Fordata. Mobilitas tim di Pulau Fordata dan Pulau Larat bervariasi tergantung pada kondisi akses menuju situs. Ada situs yang hanya dapat dijangkau dengan berjalan kaki; ada situs yang harus menggunakan speedboat; dan ada lokasi yang dapat menggunakan kendaraan darat.

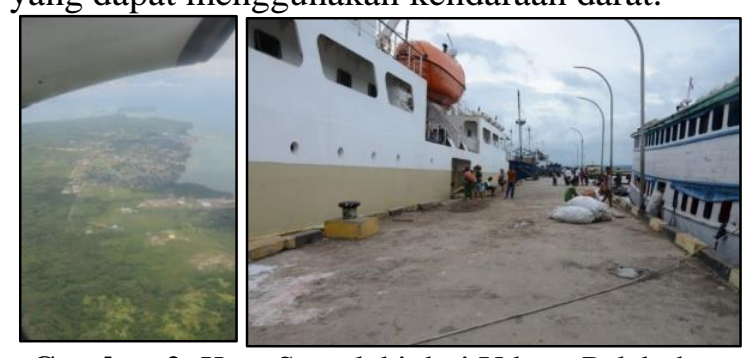

Gambar 2. Kota Saumlaki dari Udara; Pelabuhan Saumlaki

(Sumber: Balai Arkeologi Ambon 2014) 
Dalam studi awal ini, wilayah yang menjadi perhatian adalah Pulau Fordata dan Pulau Larat. Titik-titik pengamatan dilakukan meliputi beberapa desa. Di Pulau Fordata lokasi survei di lakukan masing-masing di Desa Romean; Desa Rongeur; dan Desa Awear. Sementara di Pulau Larat pengamatan dilakukan di Desa Kelaan; Desa Lamdesar Barat; dan Desa Keliobar. Pertimbangan penentuan titik-titik pengamatan ini antara lain dibantu oleh informasi dari sumber-sumber historis terkait Kepulauan Tanimbar; referensi sejarah budaya terkini terkait Kepulauan Tanimbar; informasi dari dinas terkait di Pemerintah Kabupaten Maluku Tenggara Barat; serta informasi dari Desa dan Masyarakat. Penentuan lokasi pengamatan juga berpijak pada indikasi potensi arkeologis dan sejarah budaya yang telah diketahui sebelumnya. Proses survei dan pengamatan dilakukan dengan melibatkan pemerintah desa; pemandu dari masyarakat setempat; serta tenaga lokal dan informan.

\section{Kawasan Romean}

Lokasi pengamatan pertama dilakukan di Desa Romean, Pulau Fordata. Setidaknya terdapat sepuluh titik yang direkam dalam lingkup wilayah Desa Romean. Namun hanya situs-situs yang dipandang paling potensial dan bersinggungan dengan tema penelitian ini yang dibahas di dalam artikel ini. Perhatian utama diberikan pada situs kawasan perkampungan kuno Desa Romean yang dikenal sebagai Elivavan atau Watu Eli. Kawasan ini sejatinya terbagi atas dua kawasan yaitu situs pemukiman terbuka di dataran rendah; serta perbukitan karst di sisi selatan. Kawasan ini cukup luas. Membentang dari sisi batas bagian selatan Desa Romean hingga kawasan dataran tinggi di sebelah timur desa. Karakteristik khas dari situs terbuka Elivavan ini adalah sebaran luas artefak di permukaan yang ditemukan dalam jumlah besar di sepanjang situs. Umumnya temuan permukaan diwakili oleh fragmen gerabah polos dan fragmen keramik asing dari berbagai masa.

\section{Situs Watu Eli}

Titik pengamatan kedua adalah kawasan perbukitan karst yang ada tepat di sisi selatan situs pertama. Titik tertinggi pada perbukitan karst ini adalah puncak Watu Eli. Sebagai kawasan dengan lingkungan batu gamping, situs
Watu Eli memiliki banyak ceruk dan gua bertipe gua payung. Hasil pengamatan di sekitar kawasan perbukitan karst ini menemukan sebaran temuan permukaan berupa fragmen gerabah polos dan fragmen keramik asing meski tidak dalam jumlah dominan sebagaimana yang ditemukan pada situs terbuka di sisi utaranya.

Menarik bahwa situs Watu Eli juga memiliki penanda-penanda yang melekat dengan sejarah tutur masyarakat Desa Romean. Salah satu adalah kisah Cornelis Itran Sou yang dipandang sebagai leluhur yang membentuk Desa Roeman. Di bagian tertinggi situs ini kita bisa mengamati seluruh kawasan pesisir utara Pulau Fordata, termasuk pulau-pulau tetangga seperti Larat dan Molu Maru. Di titik tertinggi ini juga terdapat sumber air yang disebut sebagai Air Watu Eli dan dalam konsep sejarah lokal masyarakat Romean dipandang memiliki daya penyembuh.

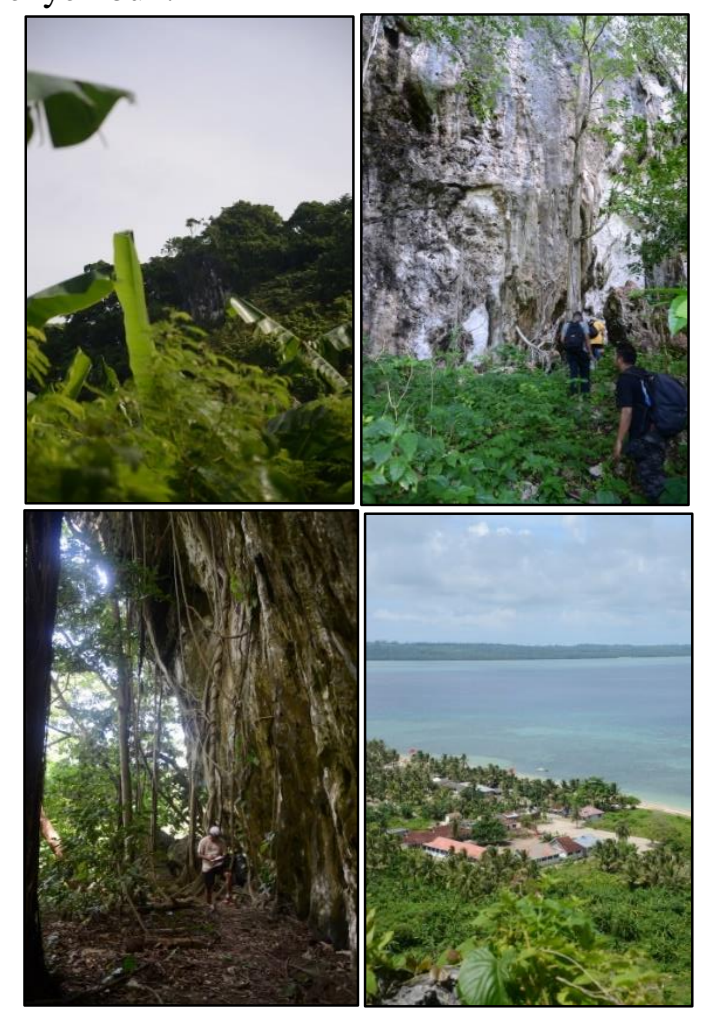

Gambar 3. Kompleks Karst Watu Eli; Tim Sementara melakukan pengamatan; Desa Rongeur dan sebagian Pulau Larat dari Ketinggian Watu Eli

(Sumber: Balai Arkeologi Ambon 2014)

Dalam kawasan kompleks Watu Eli juga ditemukan jejak penguburan tradisional yang ditandai dengan keberadaan cranium (tengkorak) Homo sapiens yang diletakan pada relung-relung dinding batu gamping. Situs ini 
disebut Batu Tengkorak. Himpunan tengkorak ini dtemukan dalam asosiasi dengan fragmen gerabah dan keramik asing. Model penguburan tradisional seperti ini memang umum ditemukan di situs-situs pemukiman kuna di Tanimbar dan pulau-pulau di bagian tenggara Kepulauan Maluku. Dalam pengamatan yang dilakukan di kawasan Watu Eli terekam setidaknya hampir selusin tengkorak manusia. Beberapa tengkorak masih dalam kondisi utuh, sementara sebagian lain sudah pecah dan rusak.
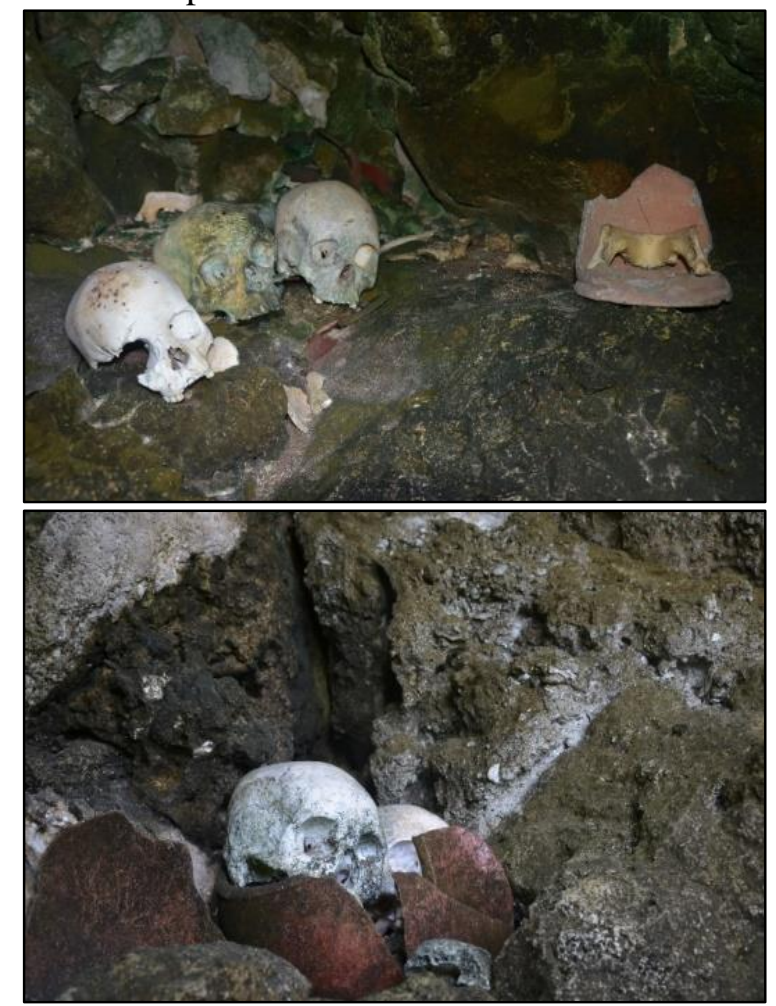

Gambar 4. Himpunan Cranium Homo sapiens di Gua Tengkorak, Desa Romean

(Sumber: Balai Arkeologi Ambon 2014)

\section{Situs Lingat Kabal}

Survei yang dilakukan di dalam lingkup Desa Romean juga merekam keberadaan situs pemukiman kuna lainnya yang dikenal sebagai Lingat Kabal. Situs ini terletak di sebelah timur Desa Romean. Dalam sejarah tutur masyarakat Romean situs Lingat dikaitkan dengan migrasi masa lalu komunitas asal Pulau Bersaidi di Lingat di Pulau Selaru. Dikisahkan bahwa komunitas ini bermigrasi setelah terjadi bencana yang disebut sebagai tenggelamnya Pulau Bersaidi. Penanda khas di situs adalah keberadaan beberapa pilar kayu yang menjadi tiang-tiang rumah masa lalu serta keberadaan sebuah meriam kuno.
Sumber-sumber sejarah tutur di Desa Romean menyebutkan bahwa keberadaan desa ini melekat dengan tokoh yang dikenal sebagai Cornelis itran Sou. Adalah keberadaan tokoh ini yang memainkan peran setral dalam awal pembentukan masyarakat Romean di masa lalu. Dalam struktur sosial masyarakat Romean, kehadiran sang tokoh kini diwakili oleh Soa atau klan Melatunan. Saat survei dilakukan, oleh marga ini, tim ditunjukkan beberapa peninggalan artefaktual khas masa kolonial yang melekat dengan kisah sang tokoh.
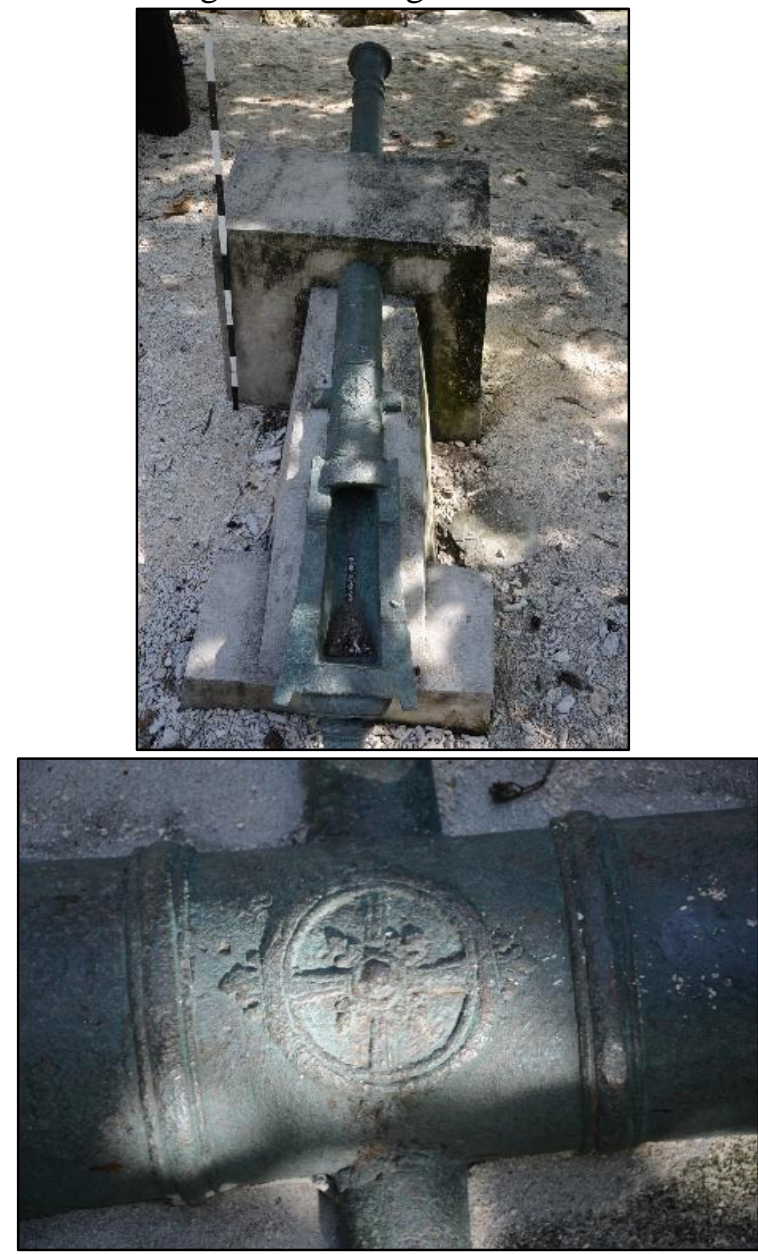

Gambar 5. Meriam Nusantara di Desa Romean (Sumber: Balai Arkeologi Ambon 2014)

\section{Kawasan Desa Awear}

Pengamatan selanjutnya dilakukan di Desa Awear yang terletak di sebelah timur laut Desa Romean. Secara administratif desa ini juga masih menjadi bagian dari Kecamatan Yaru, di Pulau Fordata. Jarak antara kedua desa ini relatif dekat. Penanda khas Desa Awear adalah lingkungan desa yang berada di dataran yang cukup tinggi dibanding kawasan sekitarnya. 
Lingkungan Desa Awear memang dibentuk oleh kawasan karst yang membentang dari pesisir hingga menuju ke bagian selatan dan timur desa ini. Tak heran, berbeda dengan desa-desa di sekitarnya, Awear memiliki sumber air yang melimpah, sebagai penanda khas kawasan karst.

Dengan lingkungan yang dibentuk oleh batu gamping, wajar jika Awear memiliki banyak kawasan gua dan ceruk. Hasil survei yang dilakukan di desa ini mendata setidaknya 11 titik gua dan ceruk. Situs pemukiman kuna yang dikenal sebagai negeri lama Kalsangur dan Negeri Lama Ahumetal juga ditinjau oleh tim. Dari 11 titik gua yang diamati, setidaknya empat titik menunjukkan indikasi aktivitas manusia masa lalu dan memiliki jejak temuan artefaktual di permukaan. Gua Yaryavan adalah salah satu yang diamati. Karakteristik gua ini adalah gua dengan dua pintu di sisi selatan dan timur. Terdapat dua bilik utama, dengan bilik terbuka yang berada pada sisi barat dan bilik tertutup pada sisi timur. Hasil pengamatan pada gua ini menemukan indikasi artefaktual berupa fragmen gerabah polos dan alat litik berupa serpih besar. Sebaran moluska juga ditemukan merata di permukaan bilik pertama. Hasil pengamatan di titik ini menunjukkan bahwa Gua Yaryavan potensial untuk dilakukan ekskavasi arkeologis.

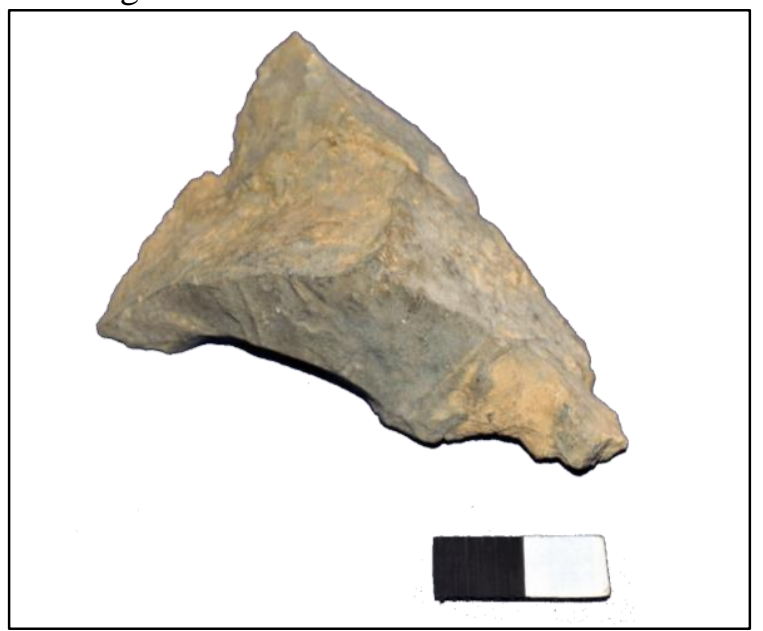

Gambar 6. Alat Serpih dari Gua Yarvavan di Fordata

(Sumber: Balai Arkeologi Ambon 2014)

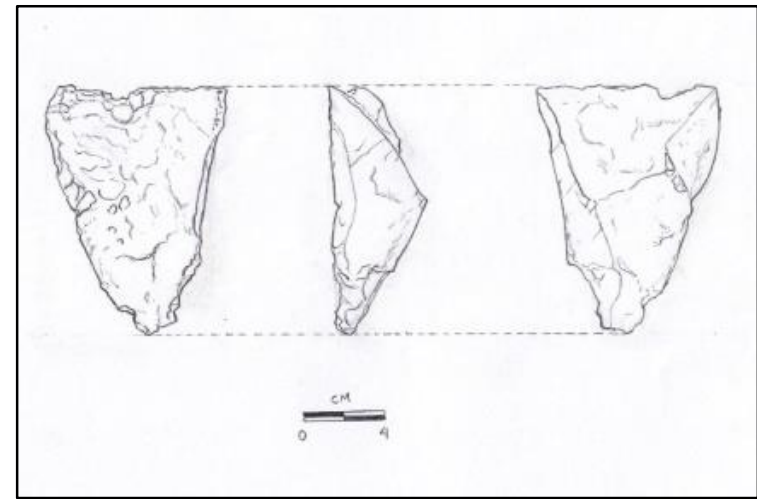

Gambar 7. Sketsa Alat Serpih dari Gua Yarvavan (Sumber: Balai Arkeologi Ambon 2014)

\section{Gua Manuk Nifan}

Lokasi gua potensial lainnya adalah $G u a$ Manuk Nifan 1. Karakteristik gua ini adalah yang paling menarik karena terletak pada relung kawasan batu gamping yang membentuk ngarai kecil dengan lereng berkemiringan cukup landai, sehingga mudah dijangkau. Konfigurasi lingkungan situs yang berada pada titik yang lebih rendah dari kawasan sekitarnya membentuk ceruk peneduh dengan pola melingkar dan gua pada sisi timur-barat. Dengan kondisi yang relatif terbuka dan berlereng, permukaan lantai ceruk senantiasa mengalami sedimentasi. Hasil pengamatan yang dilakukan di situs ini menemukan artefak berupa fragmen gerabah polos dan fragmen alat litik berupa serpih besar (flakes). Berpijak pada kondisi lingkungan; karateristik gua dan temuan permukaan, disimpulkan bahwa titik ini potensial untuk ditindaklanjuti dengan ekskavasi arkeologis.

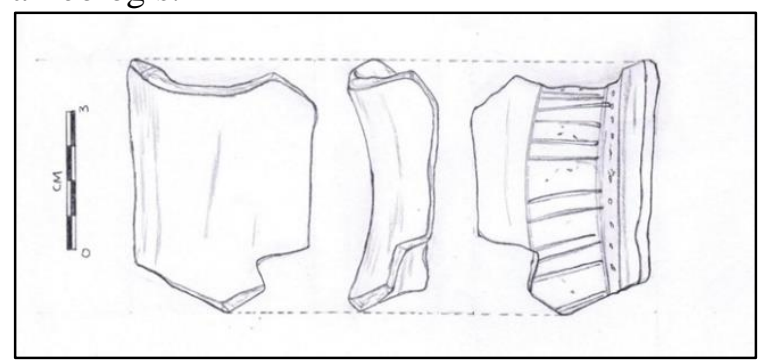

Gambar 8. Sketsa Tembikar Situs Gua Manuk Nifan di Fordata (Sumber: Balai Arkeologi Ambon, 2014) 


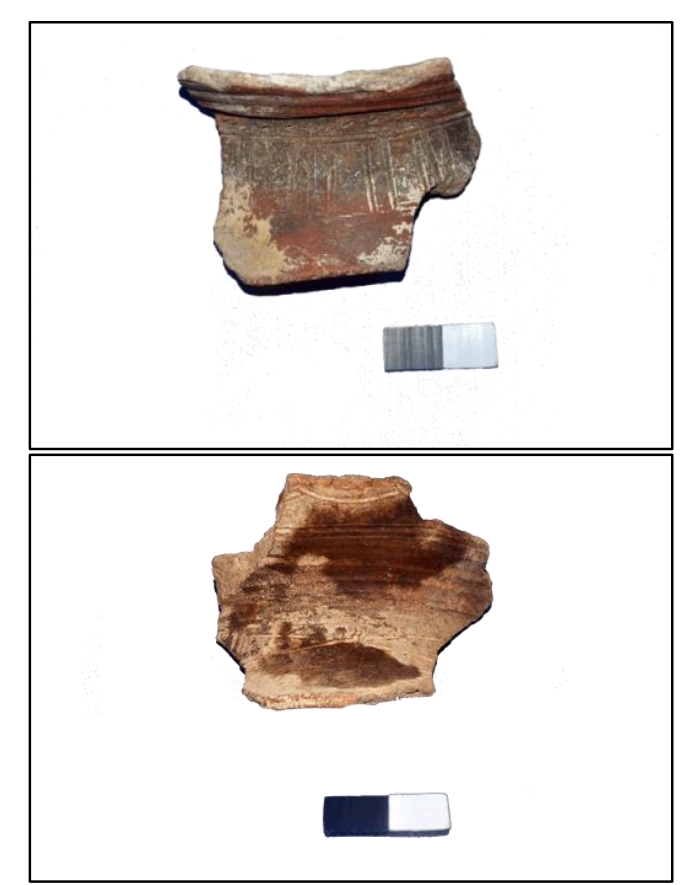

Gambar 9. Fragmen Tembikar Berhias dari Gua Manuk Nifan

(Sumber: Balai Arkeologi Ambon 2014)

Titik pengamatan selanjutnya adalah Gua Manuk Nifan. Karakteristik khas gua ini adalah keberadaan ornamen berupa stalagtit dan stalagmit yang memberi nuansa artistik pada lingkungan gua. Situs ini memiliki satu pintu masuk dengan ukuran 8,1 meter. Gua ini memiliki satu bilik tunggal dengan ukuran yang luas dan tinggi yang mencapai 10 meter. Pada bagian utara terdapat relung di langit-langit gua yang membantu pencahayaan di dalam gua. Secara umum lantai gua hampir seluruhnya tertutup oleh runtuhan langit-langit gua. Namun, terdapat beberapa bagian yang masih menyisakan sedimen untuk diamati.

$$
\text { Pengamatan yang dilakukan }
$$

menunjukkan bahwa gua ini tergolong minim gangguan manusia. Survei yang dilakukan di gua ini menemukan indikasi artefaktual yang cukup menjanjikan sebagaimana diwakili oleh lingkup temuan yang cukup bervariasi mulai dari fragmen gerabah poles merah berhias dan himpunan alat litik yang diupam. Hasil pengamatan menyimpulkan indikasi kuat tradisi masa akhir prasejarah di situs ini, sehingga gua ini harus menjadi prioritas dalam tindak lanjut ekskavasi arkeologis untuk menentukan penanggalan absolut aktivitas hunian di masa lalu.

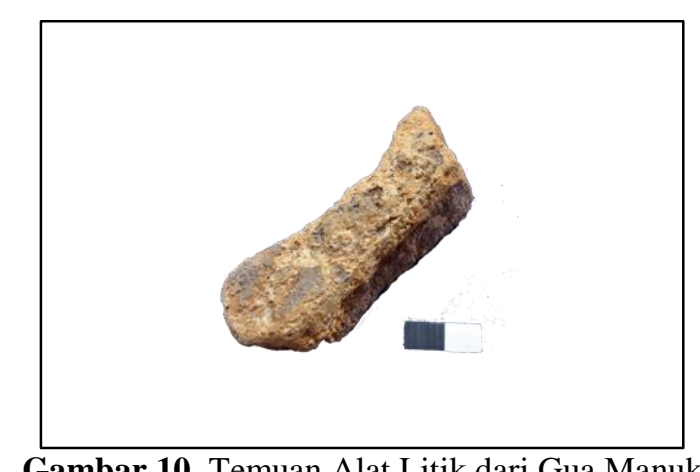

Gambar 10. Temuan Alat Litik dari Gua Manuk Nifan di Pulau Fordata (Sumber: Koleksi Penulis)

\section{Gua Vanvanvunu}
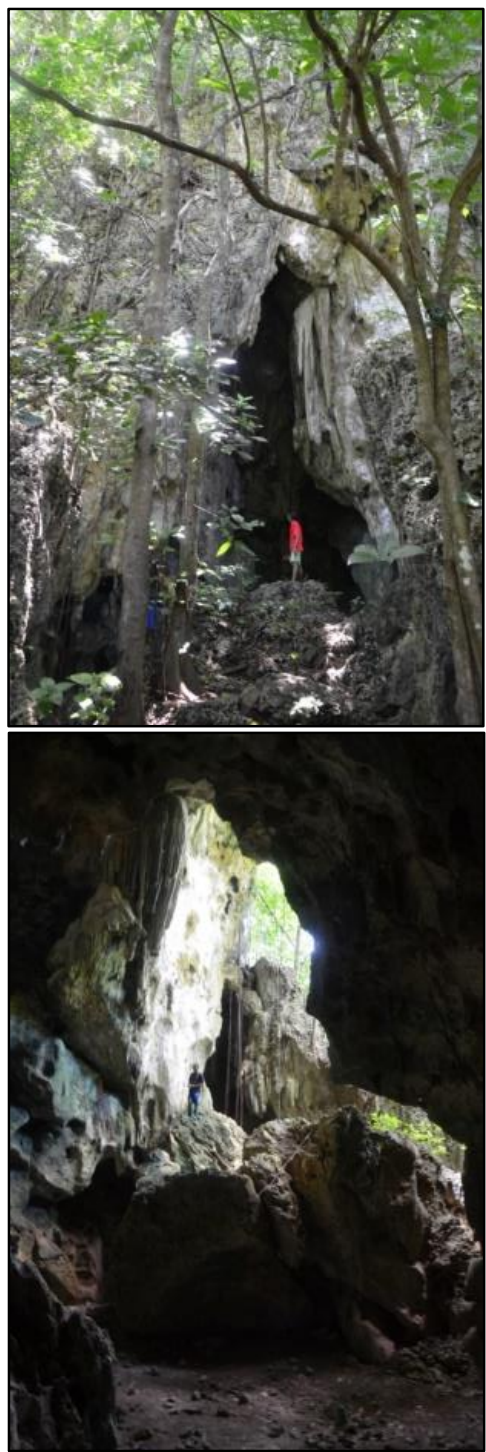

Gambar 11. Gua Vanvanvunu di Desa Awear (Sumber: Balai Arkeologi Ambon 2014)

Gua potensial lain yang diamati adalah Gua Vanvanvunu. Titik pengamatan ini 
memiliki nilai penting dalam konstruksi sejarah tutur masyarakat Desa Awear. Kepercayaan masyarakat setempat meyakini bahwa beberapa elemen ornamental berupa stalagtit disebutkan merupakan representasi simbolik dari 'pastor dan suster' yang memperkenalkan ajaran Katolik di desa ini. Gua ini terletak pada sisi timur laut Desa Awear. Karakteristik Gua Vanvanvunu ditunjukkan dengan ukuran pintu gua yang sangat besar dan ketinggian langit-langit gua yang mencapai 25 meter. Dengan kondisi yang sedemikian tak heran lantai gua ini kering dan memiliki pencahayaan yang sangat baik.

Ditinjau dari karakteristik fisik, maka Gua Vanvanvunu kiranya merupakan gua yang sangat ideal untuk hunian masa lalu. Gua ini terbagi dalam tiga bilik, dimana bilik pertama adalah yang paling ideal untuk habitasi. Sayang bahwa hasil pengamatan dalam lingkungan gua menemukan indikasi artefaktual yang minimal. Meski demikian, gua ini tetap potensial untuk ekskavasi arkeologis. Hasil pengamatan menunjukkan bahwa terdapat coretan-coretan masa kini yang menandakan praktek vandalisme yang merusak situs. Sangat disarankan bagi pemerintah desa untuk memberi perhatian guna melindungi gua yang juga memiliki nilai sejarah bagi masyarakat Awear ini.

\section{Negeri Lama Kalsangur}

Sebagaimana desa-desa lain, Awear juga memiliki situs bekas pemukiman kuna yang disebut sebagai Negeri Lama Kalsangur. Dengan bentang kawasan karst yang sedemikian luas, lokasi situs pemukiman kuna ini juga berada pada titik yang terbaik untuk perlindungan dan pertahanan. Hampir semua sisi pemukiman dikelilingi dengan tebing curam yang ketinggianannya mencapai lebih dari 30 meter. Satu-satunya akses menuju situs ini adalah jalam masuk yang berada di sisi dengan lereng yang memiliki kemiringan hingga 45 derajat dan dibentuk oleh susunan batu yang labil. Dengan kondisi yang demikian situs pemukiman kuna ini memiliki nilai pertahanan yang tinggi. Hasil pengamatan di sekitar lingkungan situs mendata sebaran gerabah polos dalam jumlah terbatas.

\section{Ceruk Tiyuvu dan Babalwan}

Titik lain yang diamati di Desa Awear adalah jejak penguburan tradisional sebagaimana nampak dalam sebaran tengkorak dan tulang manusia beserta bekal kubur si mati, seperti fragmen gerabah dan fragmen keramik asing. Terdapat dua titik ceruk dengan karakteristik penguburan tradisional yang diamati yaitu Ceruk Tiyuvu dan Ceruk Babalwanan. Kedua Ceruk ini terletak tepat di bagian timur Desa Awear.

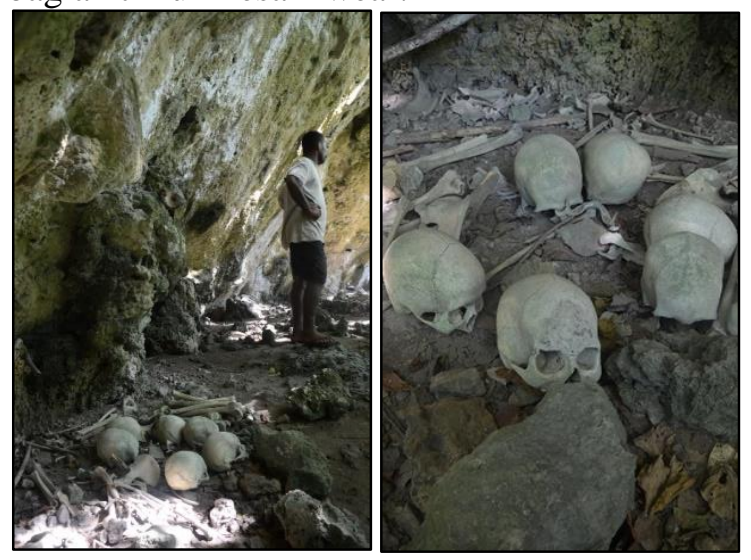

Gambar 12. Situs Penguburan Kuno Ceruk Tiyuvu di Desa Awear

(Sumber: Balai Arkeologi Ambon 2014)

\section{Negeri Lama Kelaan}

Setelah menyelesaikan pengamatan di Pulau Fordata, tim kemudian melanjutkan survei ke Pulau Larat yang berada tepat di sisi selatan Pulau Fordata. Kedua pulau ini dipisahkan oleh selat sempit. Desa Kelaan dipilih oleh tim sebagai basecamp selanjutnya dan menjadi lokasi pengamatan pertama di Pulau Larat. Secara administratif Desa Kelaan merupakan bagian dari kecamatan Larat, Kabupaten Maluku Tenggara Barat. Meski berbeda daratan, desa ini terletak berhadap-hadapan dengan Desa Romean yang berada di Pulau Fordata.

Titik pengamatan pertama di Desa Kelaan dilakukan di situs bekas perkampungan kuna yang dikenal sebagai Negeri Lama Kelaan. Situs terletak di sisi timur Desa Kelaan dan dapat dijangkau dengan menggunakan transportasi laut. Serupa dengan pemukiman kuna lain di Tanimbar, situs ini juga terletak di dataran tinggi yang sukar dijangkau. Pemukiman kuna ini berada dalam kawasan seluas hampir dua hektar. Hasil pengamatan yang dilakukan menemukan indikasi artefaktual sebaran fragmen gerabah polos serta fragmen keramik asing dalam jumlah yang cukup besar. Umumnya keramik yang ditemukan berasal dari masa Dinasti Ming. Dalam lingkup situs ini juga diamati indikasi penguburan tradisional sebagaimana diwakili 
dari keberadaan cranium Homo sapiens yang diletakkan dalam asosiasi dengan keramik asing di relung bebatuan.

Berdampingan dengan kawasan pemukiman kuna Desa Kelaan ini teridentifikasi kompleks Gua Wanlaoru. Terletak di sisi barat pemukiman, setidaknya terdapat tiga gua dan satu ceruk peneduh. Gua terbesar memiliki ukuran pintu yang lebar dengan lantai kering dan pencahayaan cukup baik di bagian depan bilik. Hasil pengamatan menemukan fragmen gerabah polos yang terletak di dua dari tiga gua. Tidak ditemukan indikasi artefaktual lainnya, namun gua ini cukup potensial untuk ekskavasi arkeologis. Secara umum kawasan pemukiman kuna Desa Kelaan ini mewakili karakteristik khas pemukiman kuna di pulau-pulau di selatan Kepulauan Maluku sebagaimana ditandai oleh keletakannya di dataran tinggi, sulit dijangkau dan berkarakter defensif.

\section{Situs Kora Tutul}

Beranjak dari Desa Kelaan, survei dilanjutkan ke Desa Lamdesar Barat. Sumbersumber etnografi yang ditinjau sebelum pengamatan lapangan oleh tim, menunjukkan patung tokoh Atuf yang diletakkan di tengah pemukiman Desa Lamdesar masa lalu. Patung ini kini menjadi koleksi Museum Tropis Amsterdam. Survei tim penelitian difokuskan pada situs negeri lama yang disebut oleh masyarakat Lamdesar Barat sebagai Kora Tutul. Situs ini terletak hampir satu kilometer di sebelah timur Desa Lamdesar Barat saat ini. Karateristik situs ditandai dengan keletakan di dataran tinggi, dan akses yang cukup sulit karena harus melalui lereng yang curam. Di sekeliling situs juga ditata susunan batu untuk memperkuat karakteristik pertahanan pada pemukiman. Temuan penting di situs ini adalah keberadaan batu meja atau dolmen. Morfologi dolmen ini adalah batu datar dengan ukuran diameter 1,3 meter yang diletakan di atas penyangga tiga buah batu. Terdapat sebuah penanda berupa ukiran antropozoomorfik dalam bentuk ular berkepala manusia dengan menggunakan anting. Hasil survei di seluruh Kepulauan Maluku belum pernah menemukan dolmen dengan pola hias. Temuan di Lamdesar ini adalah yang pertama.

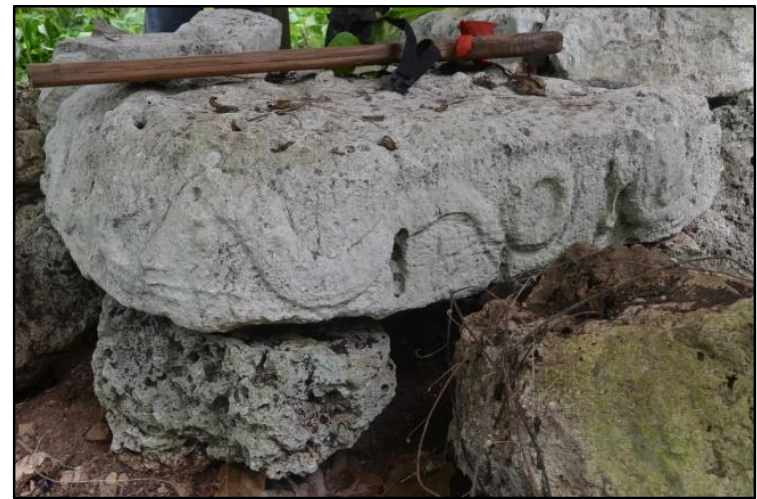

Gambar 13. Dolmen dengan Motif

Antropozoomorfik di Situs Negeri Lama Kora Tutul di Lamdesar Barat

(Sumber: Balai Arkeologi Ambon, 2014)

Temuan penting lain dari situs pemukiman kuna di Desa Lamdesar Barat adalah fragmen-fragmen gerabah berhias dalam jumlah besar yang tersebar di lereng menuju situs ini. Fragmen gerabah hias yang diidentifikasi umumnya adalah gerabah poles merah dengan pola hias geometris berupa garis, meander, dan pola hias tindik. Beberapa fragmen gerabah menunjukkan karakteristik pola hias yang khas gerabah neolitik akhir dan paleometalik. Survei arkeologis yang telah dilakukan selama empat tahun terakhir di Kepulauan Tanimbar belum pernah menemukan situs dengan sebaran fragmen gerabah hias yang sedemikian bervariasi. Agaknya kawasan situs pemukiman terbuka ini memiliki sejarah hunian yang jauh lebih tua dari yang diduga sebelumnya. Wilayah ini juga potensial untuk ekskavasi arkeologis.
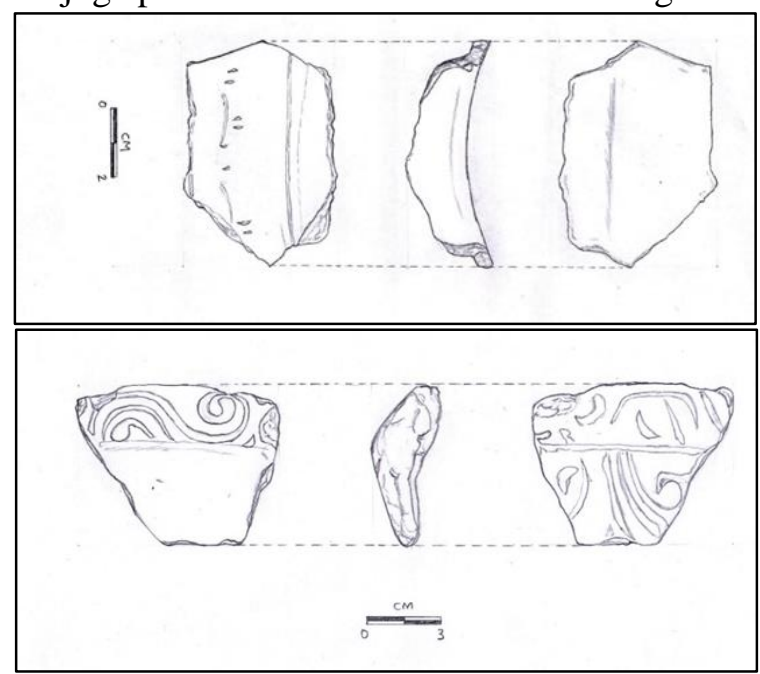


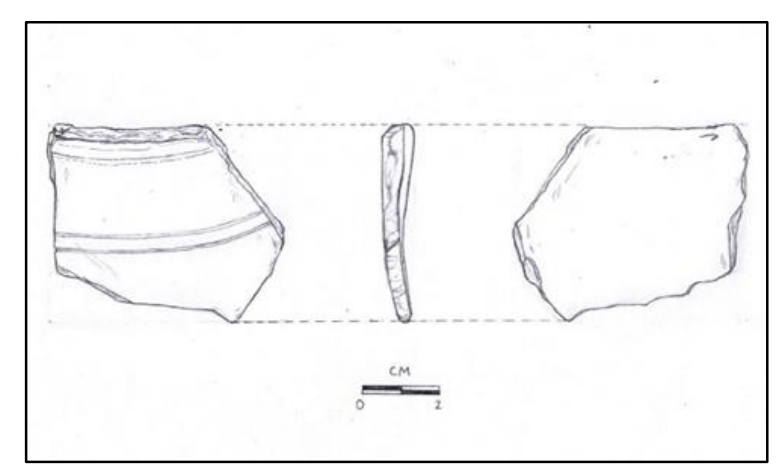

Gambar 14. Sketsa Tembikar Berhias dari Situs Negeri Lama Kora Tutul Lamdesar Pulau Larat (Sumber: Balai Arkeologi Ambon, 2014)

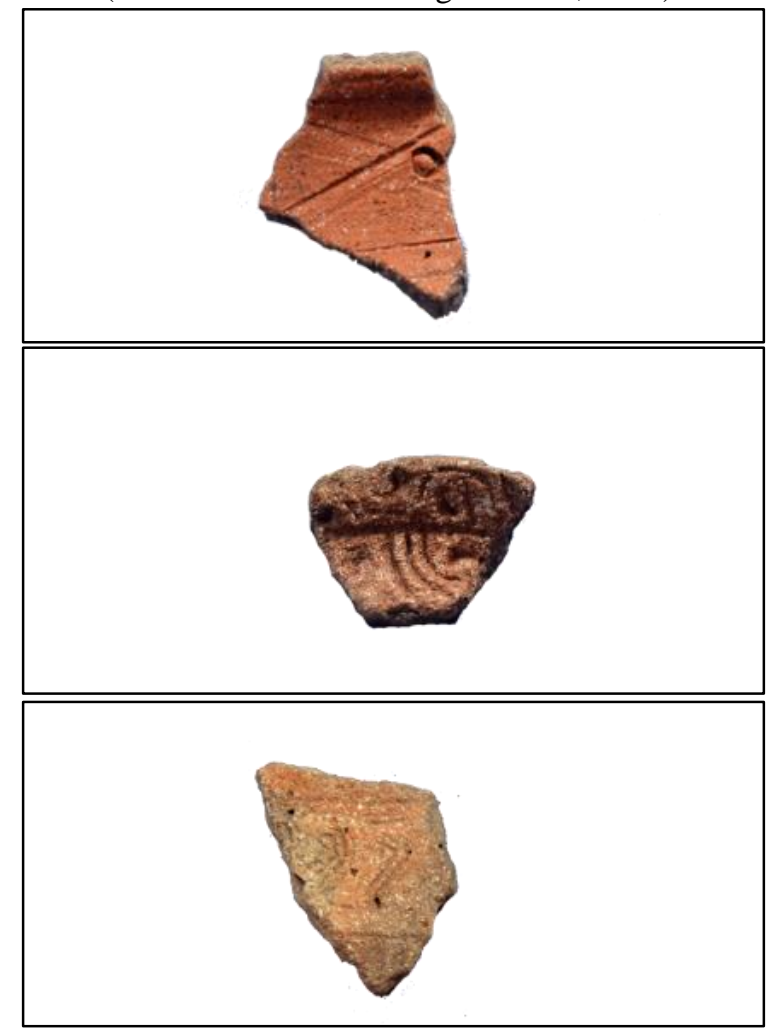

Gambar 15. Detil Sampel Fragmen Tembikar Berhias dari Situs Negeri Lama Kora Tutul Lamdesar

(Sumber: Dokumentasi Penulis)

\section{Negeri Lama Keliobar}

Titik pengamatan terakhir dalam survei ini adalah Desa Keliobar yang terletak di sebelah barat Desa Kelaan. Fokus pengamatan di desa Keliobar diarahkan pada situs negeri lama yang berada sekitar $1 \mathrm{~km}$ di sebelah barat Desa Keliobar. Berada tepat di pesisir. Penanda khas pada situs ini adalah keberadaan praktek penguburan tradisional dengan meletakkan tengkorak manusia pada relung-relung ceruk yang berada dekat dengan garis pantai. Temuan tengkorak manusia ini berasosiasi dengan fragmen gerabah polos dan keramik asing yang menjadi bekal si mati dalam praktek penguburan.

\section{Karakter Situs-Situs Arkeologi di Pulau Fordata dan Larat}

Hasil survei arkeologis yang dilakukan di Pulau Fordata dan Pulau Larat setidaknya memberikan gambaran bahwa kedua pulau ini dan kawasan Tanimbar bagian utara memiliki potensi tinggi dalam kerangka studi arkeologi dan sejarah budaya. Bila dilihat, lebih dari 50 titik dengan indikasi potensi arkeologi yang ditinjau dan direkam. Dari jumlah tersebut 11 titik dipandang sebagai lokasi yang paling potensial dan relevan dengan tujuan penelitian ini. Lebih jauh, situs-situs di atas, dapat dikelompokkan ke dalam tiga kategori berdasarkan karakteristiknya yaitu: gua dan ceruk, pemukiman kuno, dan yang terkait dengan memori sosial dan sejarah lokal.

\section{Kelompok Situs Gua Hunian dan Ceruk Peneduh}

Hasil pengamatan di Pulau Fordata menemukan bahwa wilayah ini kaya dengan potensi kawasan karst. Bentang kawasan karst dimulai dari sisi barat Desa Romean, tepat di kawasan situs Watu Eli dan berlanjut hingga Awear dan sekitarnya. Konfigurasi gamping ini masih berlanjut hingga ujung sisi barat Pulau Fordata di Desa Adodo. Tak heran survei yang dilakukan di Awear mendata sejumlah besar himpunan gua dan ceruk peneduh, meski hanya beberapa yang dipandang memiliki potensi arkeologis dan layak ditindaklanjuti. Sebaran potensi gua memang cenderung konsisten sepanjang jalur ini.

Terdapat sekitar tiga gua dan satu ceruk peneduh yang memiliki indikasi temuan permukaan yang kuat sebagai penanda adanya aktivitas habitasi di masa lalu. Selain Gua Ayarvavan, direkam juga Gua Manuk Nifan.Gua Manuk Nifan dipandang paling memiliki potensi tinggi untuk ditindaklanjuti. Keberadaan gerabah poles merah dan alat litik menjadi indikator kuat aktiVitas prasejarah di situs ini. Ekskavasi untuk mengupas lapisan budaya serta melakukan pencuplikan sampel untuk uji kronologi mutlak diperlukan di situs ini.

Keberadaan beberapa ceruk peneduh seperti ditemukan di Watu Eli dan Awear juga memperkaya kemungkinan jejak habitasi dari 
masa prasejarah. Menarik bahwa relung-relung gamping dalam bentang karst ini di Fordata banyak dimanfaatkan sebagai wahana penguburan sekunder, hal mana akan di bahas selanjutnya.

\section{Kelompok Situs Pemukiman Kuno}

Karakerstik kedua yang diidentifikasi pada situs-situs arkeologi di Pulau Fordata dan Pulau Larat adalah sebaran luas situs-situs pemukiman kuno. Situs pemukiman kuno ini kiranya umum ditemukan di Asia Tenggara hingga Oseania. Termasuk di Maluku dan Kepulauan Tanimbar. Ciri khas situs-situs ini adalah keletakan yang berada di dataran tinggi, memiliki lokasi yang sukar diakses. Umumnya hanya memiliki satu jalan menuju lokasi, dan memiliki karakter defensif sebagai sarana pertahanan sebagaimana ditunjukkan oleh keberadaan tembok keliling yang memperkuat lokasi yang sukar akses sebelumnya (de Jonge dan van Dijk, 1995; Lape 2000a; 2000b; 2006). Hasil survei di Fordata dan Larat menemukan bahwa semua desa yang disurvei memiliki situssitus pemukiman kuno. Umumnya situs-situs ini telah ditempati lintas generasi. Mengacu pada tradisi tutur, situs-situs mulai ditinggalkan setelah persentuhan dengan masa kolonial. Ketika itu, kebijakan pasifikasi menyusul penerapan politik etis di penghujung abad ke-19 mendorong pemerintah kolonial untuk merelokasi masyarakat yang berdiam di lokasilokasi yang sukar diakses menuju daerah pesisir yang lebih terbuka dan mudah diakses.

Hasil studi arkeologis terkait situs-situs pemukiman kuno dengan karakteristik ini telah memberikan gambaran kronologis bahwa situssitus ini mulai berkembang pada awal masa sejarah dan mencapai puncaknya pada abad ke14 hingga abad ke-17. Tesis yang umum diterima adalah bahwa kemunculan situs-situs dengan karakteristik defensif ini terkait erat dengan meningkatnya ekskalasi konflik dan perang antar komunitas di masa itu sebagai dampak perubahan iklim ekstrim yang berdampak pada keterbatasan sumber daya alam. Persaingan akses pada sumber-sumber penghidupan ini yang kemudian menjadi awal konfik dan perang yang bermuara pada tumbuh kembang situs-situs pemukiman berciri pertahanan

Hasil survei di Pulau Fordata dan Pulau Larat mengkonfirmasi sebaran luas situs-situs ini di Kepulauan Tanimbar. Serupa dengan situssitus sejenis di Yamdena dan pulau-pulau yang lebih ke selatan, situs-situs berciri pertahanan juga menjadi ciri khas dari pemukiman kuno yang disebut sebagai negeri lama oleh masyarakat setempat. Mulai dari selatan hingga ke utara situs-situs ini teridentifikasi dan berasosiasi dengan identitas dan sejarah asal usul desa sebagaimana ditemukan di Roeman, Awear, Kelaan, Lamdesar hingga Keliobar. Menarik bahwa di situs pemukiman kuno di desa Lamdesar, masih ditemukan jejak-jejak tradisi megalitik sebagaimana diwakili oleh dolmen dengan motif antropozoomorfik di situs pemukiman kuno.

\section{Kelompok Situs Penguburan Sekunder}

Memperkuat hipotesis mengenai kemunculan situs pemukiman kuno sebagai akibat konflik dan perang adalah keberadaan situs-situs penguburan sekunder yang keletakannya seringkali berasosiasi dengan situs pemukiman kuna itu sendiri. Karakteristik khas dari situs penguburan sekunder ini adalah bahwa di situs ini umumnya hanya ditemukan cranium atau tengkorak dari manusia. Tidak ditemukan bagian-bagian tubuh lain. Dengan pengecualian di Awear. Sejarah tutur masyarakat setempat di desa-desa yang disurvei umumnya memiliki kisah bahwa tengkorak-tengkorak ini adalah kepala musuh yang dipenggal sebagai bagian dari tradisi mengayau dan perang. Sumbersumber etnohistori memang mengkonfirmasi mengenai sejarah konflik antar desa dan tradisi mengayau yang pernah berkembang di Kepulauan Tanimbar dan Pulau Selaru. Sebagaimana antara lain dituturkan oleh Etnograf Drabbe dan ahli alam Inggris Forbes (1882 dalam Miller, 2012). Data ini kiranya relevan dengan keberadaan situs-situs pemukiman kuno berciri defensif sebagai implikasi tingginya konflik antar komunitas tersebut.

Tentu pada beberapa desa ada pengecualian, bahwa ceruk-ceruk yang digunakan sebagai penguburan tidak semata untuk menampung kepala musuh, namun juga sebagai penguburan komunitas di masa lalu. Informasi masyarakat di Desa Awear menyebutkan bahwa lokasi penguburan yang ditinjau tim juga menjadi tempat penguburan leluhur di masa lalu. Informasi ini kiranya relevan utamanya bila mengacu pada data 
etnohistori tentang penguburan di Tanimbar sebagaimana yang ditulis oleh Drabbe (1940). dalam bukunya Etnografi Tanimbar.

Di buku tersebut Drabbe menjelaskan mengenai praktek penguburan masyarakat Tanimbar hingga permulaan abad ke-20 dimana jenazah si mati akan di biarkan di alam terbuka hingga membusuk dan mengering. Selanjutnya bagian cranium dan tulang leher akan disimpan oleh keluarga di altar rumah dan bagian kerangka tubuh akan dibiarkan atau dikuburkan. Mengamati karakter situs-situs penguburan ini kiranya relevan dengan apa yang ditulis oleh Drabe masa itu.

Saat ini situs-situs penguburan sekunder ini menjadi lokasi memori sosial yang terkait dengan sejarah desa dan komunitas. Difungsikan sebagai tempat sakral, situs-situs ini seringkali masih menjadi bagian dari kepercayaan lama yang secara terbatas masih dipraktekkan, meski mayoritas penduduk telah memeluk agama nasrani. Hal ini dapat diamati dari keharusan melakukan ritual oleh para tetua, sebelum tim mengamati situs-situs ini, serta keberadaan aneka sesaji masyarakat yang ditempatkan di situs-situs ini.

\section{Arah Studi Lanjutan dan Pengembangan Potensi}

Bercermin pada potensi arkeologi dan karakteristik situs-situs di atas, kiranya jelas bahwa Pulau Larat dan Fordata sebagai pulau utama di Kepulauan Tanimbar bagian utara, kaya dengan potensi kepurbakalaan dan sejarah budaya. Karakteristik potensi yang dimiliki juga mempunyai ciri yang bertautan dengan tematema studi arkeologi dan sejarah budaya dalam kawasan. Hal mana kiranya memberi ruang bagi arkeologi Pulau Fordata dan Pulau Larat untuk ditinjau kembali dan dikembangkan lebih lanjut baik dalam kerangka studi-akademis arkeologi maupun pengembangan untuk tujuan yang lebih luas. Berikut beberapa aspek yang kiranya dapat ditindaklanjuti dalam bingkai riset arkeologi serta pengembangan potensi.

\section{Pemetaan dan Ekskavasi Situs-Situs Pemukiman Kuno}

Survei yang dilaksanakan pada tahun 2014 secara umum telah mengidentifikasi situssitus pemukiman kuno yang ada di Pulau Fordata dan Pulau Larat. Termasuk dalam kegiatan survei ini adalah plotting untuk mengamati sebaran situs serta pemetaan aspek bentuk situs dalam sketsa. Mengamati kembali sebaran luas dan profil situs yang cukup kompleks dengan keterkaitan dalam tema penelitian kawasan, kiranya dirasa perlu untuk melakukan pemetaan secara lebih komprehensif atas aspek formal situs terutama dalam kaitan dengan keletakan dalam bentang lahan dan asosiasi yang lebih rinci dengan lingkungan. Aktivitas ini kiranya dapat diperkaya dengan melakukan ekskavasi dan coring untuk melakukan pencuplikan dan uji petik sampel untuk kepentingan uji kronologi. Hal mana akan mempertegas kronologi situs dan memberikan gambar yang lebih jelas tentang proses tumbuh kembang situs-situs di Larat dan Fordata dalam kaitan dengan situs-situs serupa di kawasan sekitar (Ballard, 1988; Birdsell, 1977).

\section{Sejarah Tutur}

Aspek kedua yang dapat didalami adalah menghimpun sejarah tutur masyarakat setempat. Serupa dengan tempat-tempat lain di Kepulauan Tanimbar dan Maluku, tradisi menulis tidak dikenal di Pulau Fordata dan Larat hingga kedatangan orang-orang Eropa. Sebagai implikasinya, pengetahuan masa lalu hanya diteruskan secara verbal melalui tradisi tutur. Termasuk dalam kaitan dengan asal usul masyarakat, proses migrasi, konflik dan perang hingga memori sosial terkait situs-situs arkeologi. Pengetahuan terkait sejarah tutur kiranya merupakan salah satu sumber data yang dipandang dapat memberi bobot dalam kerangka pengetahuan lokal dan memperkaya data arkeologi yang dikumpulkan. Meski memiliki potensi dari segi akademis, belum ada kajian yang secara khusus berupaya menghimpun pengetahuan sejarah tutur yang kini mulai langka ini.

\section{Ekskavasi di Situs Gua dan Pemukiman untuk data Kronologi}

Serupa dengan situs-situs pemukiman kuno, kawasan karst dengan ceruk dan gua di Fordata dan Larat jelas memiliki potensi untuk ditindaklanjuti melalui studi arkeologi. Ragam temuan permukaan yang teridentifikasi di berbagai situs ceruk dan gua menjadi indikator aktivitas manusia masa lalu sekaligus penanda awal bagi kegiatan ekskavasi. Mengamati geografi Fordata dan Larat yang menjadi pulau paling utara di Tanimbar, yang bertautan dengan 
Kepulauan Kei di Timu,r pulau ini kiranya memiliki potensi untuk ditinjau dalam kerangka upaya menemukan jejak-jejak kontak dan interaksi antara kedua kawasan. Dalam sudut pandang yang lebih luas, menimbang geografi Fordata dan Larat sebagai bagian dari Kepulauan Tanimbar yang terletak berbatasan dengan daratan besar Australia, terbuka kemungkinan untuk ditelaah dalam kaitan dengan skenario migrasi manusia masa lalu dari daratan dan Kepulauan Asia Tenggara menuju Australia atau sebaliknya (Birdsell, 1977; Spriggs, 1988; Spriggs dan Miller, 1988; O'Connor et al, 2005; Tanudirdjo, 2005). Pencuplikan sampel untuk uji kronologi dan ekskavasi arkeologis kiranya menjadi pilihan paling relevan untuk menemukan kemungkinan yang lebih jauh atas tesis di atas.

\section{Publikasi potensi kepurbakalaan pulau terdepan}

Aspek terakhir namun memiliki nilai paling penting kiranya melekat pada pengembangan segenap pengetahuan arkeologi dan sejarah budaya serta potensi kepurbakalaan yang ada di Larat, dalam kaitannya dengan pengembangan wilayah ini sebagai salah satu pulau terdepan (Gesit, 2009; Retraubun, 2006; Zuhdi, 2006). Menimbang kedekatan geografi dan budaya, lebih relevan kiranya jika Pulau Fordata juga ditautkan dalam isu pengelolaan ini. Bagi masyarakat di wilayah perbatasan, kebutuhan-kebutuhan dasar seperti listrik, akses jalan, serta perhubungan dan fasilitas kesehatan tentu lebih mendesak. Meski demikian, bercermin pada antuasiasme dan semangat masyarakat dalam kegiatan survei, jelas bahwa ada kebanggaan dan harapan yang diletakkan agar kekayaan sejarah budaya setempat dapat diangkat untuk lebih dikenal. Tentu, pilihan utama pasca aktivitas riset adalah publikasi ilmiah sebagaimana antara lain diwakili oleh tulisan ini. Publikasi atas kekayaan potensi pusaka juga telah dilakukan lewat media. Melalui aktivitas seperti ini, meski terbatas, sejatinya penelitian arkeologi diharapkan mampu berperan sebagai jembatan untuk memberi tempat bagi kekayaan budaya di LaratFordata dan pulau-pulau terdepan lain dalam ruang-ruang akademis nasional. Harapannya pun sederhana, bahwa pengetahuan masa lalu ini setidaknya dapat diabadikan dalam kerangka akademis. Harapan lebih jauh tentu saja agar lokasi-lokasi yang dipandang paling potensial, dapat diregistrasi sebagai situs cagar budaya baik dalam kerangka nasional, propinsi ataupun kabupaten. Hal mana akan menjadi langkah awal bagi kemungkinan pengelolaan yang lebih baik untuk segenap pusaka di tapal batas negara ini ke depan.

\section{KESIMPULAN}

Kepulauan Tanimbar merupakan salah satu wilayah di Maluku yang kaya dengan potensi sejarah budaya dan kepurbakalaan. Hal mana ditunjukkan dalam berbagai referensi akademis internasional terkait kebudayaan Tanimbar. Benda budaya asal kepulauan ini juga tersebar dan menjadi mahakarya di berbagai museum dunia. Sayang, meski dengan potensi yang sedemikian, studi arkeologi di wilayah ini terbilang minim. Sejumlah studi arkeologi awal memang telah dilaksanakan, namun umumnya hanya menjangkau wilayah bagian selatan Kepulauan Tanimbar.

Penelitian ini difokuskan pada wilayah Kepulauan Tanimbar Bagian Utara dengan perhatian pada Pulau Larat dan Fordata. Kedua Pulau ini penting karena merupakan wilayah yang pernah diulas dalam sumber-sumber kolonial klasik tentang Kepulauan Tanimbar. Larat dan Fordata juga merupakan bagian dari pulau-pulau terdepan di perbatasan negara sehingga memiliki nilai strategis dalam kerangka pengelolaan wilayah negara.

Pendekatan penelitian dilakukan dengan metode survei penjajakan dan berhasil merekam lebih dari 50 titik pengamatan. 11 titik pengamatan dipandang sebagai lokasi yang paling potensial dan diulas dalam makalah ini. Hasil penelitian menemukan bahwa karakter potensi situs arkeologi di Pulau Larat dan Fordata dapat dibagi dalam tiga kategori yaitu: pertama, kelompok situs gua hunian dan ceruk peneduh; kedua, kelompok situs pemukiman kuno; dan ketiga kelompok situs penguburan sekunder. Karakter temuan permukaan didominasi oleh fragmen alat litik dan tembikar, baik polos dan berhias. Diidentifikasi juga sebaran fragmen tulang manusia di situs-situs penguburan sekunder. Sebuah dolmen dengan motif antropozoomorfik diidentifikasi di salah satu situs.

Secara umum dapat disimpulkan bahwa wilayah Larat dan Fordata kaya dengan potensi situs arkeologi dan layak untuk ditindaklanjuti. 
Ada empat aspek yang kiranya perlu menjadi perhatian dalam pengelolaan potensi arkeologi di Pulau Larat dan Fordata ke depan. Pertama, pemetaan dan ekskavasi situs-situs pemukiman kuno; Kedua, perekaman sejarah tutur dalam pengembangan sejarah lokal; Ketiga, adalah ekskavasi situs gua untuk data kronologi; Keempat adalah pembuatan monografi dan publikasi potensi arkeologi di Pulau Larat dan Fordata dalam kaitannya dengan pengembangan pulau terdepan dan kawasan perbatasan di Indonesia.

\section{Ucapan Terima Kasih}

Ucapan terima kasih dan penghargaan disampaikan kepada Pemerintah Kabupaten Maluku Tenggara Barat yang mendukung pelaksanaan penelitian ini. Penghargaan dan ucapan terima kasih juga disampaikan kepada Bapak Yongky Souissa, Kepala Badan Pemberdayaan Masyarakat Desa Kabupaten Maluku Tenggara Barat untuk semua dukungan dan bantuan kepada tim. Kepada saudara Muhammad Al Mujabuddawat dari Balai Arkeologi Ambon disampaikan juga terima kasih untuk penggambaran sketsa temuan dalam tulisan ini.

$* * * * *$

\section{DAFTAR PUSTAKA}

Aryanto, Gesit. 193 Titik Dasar, 92 Pulau Terluar dalam Kompas 7 November 2009.

Ballard, C. (1988). Dudumahan: a rock art site on Kai Kecil, Southeast Mollucas. Bulletin of the IndoPacific Prehistory Association, 8, Canberra: Australia National University pp. 139-161.

Birdsell, J.B. (1977). The recalibration of a paradigm for the first peopling of Greater Australia, in J. Allen, J Golson, and R. Jones (eds.) Sunda and Sahul, p. 113-167.

De Jonge, N and van Dijk, T. (1995). Forgotten Islands of Indonesia: The Art and Culture of the Southeast Mollucas. Singapore: Periplus.

Drabbe, Petrus. (1940). Etnografi Tanimbar. Leiden; E.J Brill.

Lape, P.V. (2000a). Contact and Conflict in the Banda Islands, Eastern Indonesia, 11th to 17th Centuries. Unpublished $\mathrm{PhD}$ thesis, Brown University, Rhode Island.

Lape, P.V. (2000b). Political dynamics and religious change in the late pre-colonial Banda Islands, Eastern Indonesia. World Archaeology 32(1). London: Routledge pp. 138-55.
Lape, P. (2006). Chronology of fortified sites in East Timor. In Journal of Island and Coastal Archaeology 1. Pp 285-297.

Le Bar, F.M. (1976). Insular Southeast Asia: Ethnographic Studies. Connecticut: New Haven.

McKinnon, S. (1988). "Tanimbar Boats," dalam Islands and Ancestors: Indigenous Styles of Southeast Asia (eds J.P Barbier and D. Newton). New York: The Metropolitan Museum of Art, hal. 152-169.

Miller, George. (2012). Indonesia Timur Tempo Doeloe. Jakarta: Komunitas Bambu.

Retraubun, Alex. Mengapa Terluar bukan Terdepan. Dalam Kompas 20 September 2006.

Ririmasse, M. (2005). Jejak dan Prospek Penelitian Arkeologi di Maluku. Dalam Kapata Arkeologi Volume 1 No. 1. Ambon: Balai Arkeologi Ambon.

Ririmasse, M. (2006). Aspek-Aspek Kronologi Arkeologi Kolonial di Pulau Kisar. Dalam Berita Penelitian Arkeologi Volume 2 No. 1. Ambon: Balai Arkeologi Ambon.

Ririmasse, M. (2007). Penelitian Arkeologi di Desa Lingat Pulau Selaru Kabupaten Maluku Tenggara Barat. Dalam Berita Penelitian Arkeologi Volume 3 No. 4. Ambon: Balai Arkeologi Ambon.

Ririmasse, M. (2007b). Fragmen Moko dari Selaru: Temuan Baru Artefak Logam di Maluku. Dalam Berita Penelitian Arkeologi Volume 3 No. 5. Ambon: Balai Arkeologi Ambon.

Ririmasse, M. (2008). Visualisasi tema perahu dalam rekayasa situs arkeologi di Maluku. Dalam Naditira Widya Volume 2 No. 1. Banjarmasin: Balai Arkeologi Banjarmasin.

Ririmasse, M. (2008b). Archaeology Goes to School: Mengemas Pengetahuan Warisan Budaya sebagai Muatan Lokal. Pertemuan Ilmiah Arkeologi XI Solo, 13-16 Juni 2008.

Ririmasse, M. (2010). Boat Symbolism and Identity in the Insular Southeast Asia: A Case Study from the Southeast Moluccas. Tesis Pascasarjana. Tidak diterbitkan. Leiden: Rijkuniversiteit Leiden.

Ririmasse, M. (2010b). Arkeologi Pulau-Pulau Terdepan di Maluku: Sebuah Tinjauan Awal. Kapata Arkeologi Vol 6 No 12. Ambon: Balai Arkeologi Ambon.

Ririmasse, M. (2011). Laut untuk Semua: Materialisasi Budaya Bahari di Kepulauan Maluku Tenggara. Makalah disampaikan dalam Evaluasi Hasil Penelitian Arkeologi 2011. Banjarmasin 2011.

Spriggs, M. (1998b). Research questions in Maluku archaeology. dalam Cakalele 9: 49-62.

O’Connor, S., Spriggs, M. Veth, P. (2005). The Aru Island in Perspective dalam O'Connor, Sue 
et.al. The Archaeology of the Aru Island. Canberra: Pandanus Books.

Spriggs, M. \& D. Miller. (1988). A previously unreported bronze kettledrum from the Kai Islands, eastern Indonesia. Indo-Pacific Prehistory Association Bulletin 8. Canberra: Australia National University. pp.79-88.

Tanudirdjo, D. (2005). The dispersal of Austronesianspeaking people and the ethnogenesis of Indonesian people. In Austronesian Diaspora and the Ethnogeneses of People in Indonesian Achipelago. Jakarta: LIPI Press.

Zuhdi, Susanto. Mengapa Bukan Pulau Terdepan dalam Kompas 8 September 2006. 